DOI: 10.1515/ausp-2017-0015

\title{
The Notion of the Foreign in Hungarian and Bulgarian Phraseologisms
}

\author{
Lilyana LESNICHKOVA \\ Sofia University “St. Kliment Ohridski” (Bulgaria) \\ Department of Classical and Hungarian Studies \\ lesznicskova@gmail.com
}

\begin{abstract}
The confrontation between the native and the foreign is a problem that focuses research efforts on a number of humanities, e.g. cultural studies, anthropology, linguistics, ethnography, etc. The following report analyses the notion of the foreign, the other, the different, reflected in the phraseological wealth of the Hungarian and Bulgarian languages. The reviewed phrasemes concentrate the shock upon collision with the different or evaluation of the experience gained in the continuous communication with the other. The foreign is usually individualized by outlining and exaggerating some of its characteristics using parallels, oppositions, and metaphors. The negative attitudes and judgments prevail over the others: the fear of the collective "I" losing its own identity creates a negative attitude towards the foreign, distorted, or wrong notion of the other and the different. Many of the idioms reflect interethnic relations from times long gone, and so they are no longer a significant part of the active vocabulary of Hungarians and Bulgarians. Their analysis, however, is of great interest as they preserve the collective memory of the Hungarian and Bulgarian cultural communities and reveal their traditional notions and knowledge.
\end{abstract}

Keywords: contrastive phraseology, phrasemes, national stereotypes, ethnonyms

It is a well-known fact that a significant part of the cultural memory of every language community is encoded in its phraseology. The idioms refer to the realia of the given culture, carry significant ethno-cultural information, and have various connotations. The purpose of the present article is to examine in the light of phraseology what images are present and passed on about strangers in the public consciousness of Hungarians and Bulgarians.

The distinction between the "I", i.e. the speaker as the centre of communication, and the "not I", i.e. you, he/she, they, forms the basis of the attitude towards the foreign, which draws a line between the private sphere of the individual and the surrounding world. 
Generalizations manifesting themselves in evaluating the foreign, the other, the different have been present for a long time and cemented themselves by comparison to one's own cultural patterns throughout the centuries. People immortalized their impressions from their encounters and contact with the other in similes, phraseological units, and proverbs and clearly individualized the strangers by highlighting or exaggerating some of their characteristics: fösvény, mint a skót 'niggard like a Scot' (Bulgarians say that stinginess is typical of Jews: стиснат като евреин); еrós, mint a zsidó vallás 'strong like the Jewish religion'; erótlen, mint a tót kaszás 'powerless like a Slovak mower'; annyian vannak, mint az oroszok 'they are as many as the Russians'; megszokja, mint cigány a verést ( török a pipát) 'get used to it like a Gypsy to drubbing ( a Turkish to a pipe)'; ráncos, mint a szász csizma 'wrinkled like Saxon boots'; sovány, mint a sváb lábszár 'thin like a Swabian leg'; szemérmes, mint a rác menyasszony 'shy like a Serbian bride'; búsul, mint a lengyel 'bewail like a Polish'; пуши като дърт циганин 'smokes like an old gypsy'; пиян като казак 'drunk like a Cossack' = iszik, mint a bécsi német 'drink like a Viennese German' iszik, mint a berényi török 'drink like a Turkish from Bereny'; дрипава като ичианка 'tattered like a gypsy'; грък като вълк 'a Greek is like a wolf'; кисел като турчин на рамазан 'in a sour mood like a Turkish during Ramadan = very angry'; въртя се кат обран евреин 'cannot find one's place like a robbed Jew = anxiously looking for someone who can help'; като влашка престилка 'like a Vlach apron = a person who changes their opinion according to the circumstances'.

Strangers are interesting because they differ from the rest in terms of language, culture, and mentality.

Both the Hungarian and the Bulgarian languages have certain ethnically specific notions due to their speakers' historic, geographic, and cultural experiences, which are built on relationships with other nations or social groups. They express the shock caused by the first collision with otherness or the evaluation of experiences accumulated through being in touch with strangers for a long time.

The different attitudes towards strangers manifest themselves in derisive or pejorative usage of ethnonyms: tót (Slovak), oláh (Vlah/Romanian), sváb (Swabian), ruszki (Russian), or polyák (Polish) are all somewhat degrading and dismissive; nigger (a black person) and jenki (Yankee) are derisive, digó (Italian) is mocking and the word skót (Scottish) can actually mean miserly in Hungarian. The words used to name gypsies in Bulgarian have negative overtones, e.g. мангал $\sim$ манго джипси мангасар; византиеи фанариот 'offensive name for a Greek'; чифутин 'offensive word for a Jew'; арнаутин 'Albanian, figurative meaning = a bad, tyrannical person'; anam 'apacs = thief'; турчин кръстен турчин 'Turkish baptized Turkish = tyrant'.

Sometimes the names of ethnic or religious groups that were thought to be hostile were/are used to name diseases as well as harmful or disgusting animals 
and plants: német has (German stomach) 'diarrhea', német rák (German crab) 'frog', angolkór (English disease) 'rachitis', franc (French disease) 'old vernacular name of syphilis', svábbogár (Swabian bug) 'cockroach’, cigánybúza (Gypsy wheat) 'weed', cigánygomba (Gypsy mushroom) 'poisonous mushroom', cigánytök (Gypsy squash) 'squash only good for fodder', zsidócseresznye (Jewish cherries) 'weed or ornamental plant', spanyolnátha (Spanish cold) 'a serious flu', поганеи 'Pagan - meaning of rat'; арнаутска чушка 'Albanian pepper = small, very hot pepper', казашки бодил 'Cossack thorn = weed (Hantium spinosum)'.

It has to be noted, however, that an ethic name cannot, in itself, be offensive or endearing, pretty or ugly. If there are more than one names for a denotation, they will be split functionally or semantically: cigány $\sim$ roma $\sim$ gácsi $\sim$ brazil $\sim$ füstös rézbórú nem a naptól barna...; ${ }^{1}$ orosz $\sim$ muszka ruszki; német germán sváb labanc fritz tokos; zsidó bibsi biboldó kóbi egyiptomi székely kajman másvallású izraeli izraelita; amerikai jenki amerikánus amсsi ami; румънии власи мамалигари 'a noun formed by the word mamaliga, puliszka'; унгарец маджар (ин); руснак казак мужик рашън; евреин чифут(ин) жид 'Jew'; циганин ром мангал манго джипси мангасар катунар 'Gypsy'; византиеи фанариот 'offensive name for a Greek'; турчин кръстен турчин пискюл $\sim$ фес, рязан пищов 'Turkish baptized Turkish = tyrant, tassel, tarboosh, circumcised').

Different ethnonyms are used in different situations and contexts, and not only as denominations but as qualifications as well. Certain social, not linguistic processes determine the usage of a particular word. In the chain германци - немци - шваби - дойчовци - прусаци , the first two are opposing denominations of formal and informal usage and have equal importance in everyday spoken language, whereas the others are negatively charged.

As time goes by, the names of certain nations or social groups go through semantic changes. They are given positive or negative connotations and thus become tools for stereotyping. By contrasting and comparing the foreign with the familiar, words and expression are (or can be) born that, on the one hand, reflect the language users' view of the world and summarize their concepts and opinions and, on the other hand, reveal their emotional approach to the phenomena of the world. Stereotypes make it possible to keep one's identity, strengthen the sense of belonging within a group and make it easier to identify with that group and, at the same time, are a component of identity (see Bańczerowski 2007: 76). The identity of a national group is born and shaped through connections and frictions with other groups and neighbours. As an individual's sense of identity can only be formed relative to a certain group, similarly, the identity of a group can only be filled with meaning after constant confrontations with nearer or more distant groups.

1 Attila József Balázsi mentions more than 30 words to denote gypsies (see Balázsi 2001). 
It is worth noting the predomination of stereotypes leading to the occurrence of language units, lexical phrases, and expressions with negative connotations: rút, mint a francia orr 'ugly like a French nose'; járkál, mint zsidó (örmény) az üres boltban 'go about like a Jew (Armenian) in an empty store'; órült spanyol 'a crazy Spanish meaning a person who does absurd things'; cigányútra megy 'takes the Gypsy road, i.e. to go the wrong/bad way'; изпаднал германеи 'down-at-heel German'; nincs rosszabb a szegény zsidónál 'there is nothing worse than a poor Jew'; adj a tótnak szállást, kiver a házadból 'give shelter to the Slovak, and they will drive you away from home; мълчи като турско гробище 'keep silent like a Turkish cemetery'; гол като арнаутски пищов 'naked like an Albanian pistol = meztelen, mint a cigánygyerek 'naked like a Gypsy kid'; като влашка престилка 'like a Vlach apron $=$ a person who changes their opinion according to the circumstances,' etc.

The explanation for that phenomenon is that "there is a fear behind stereotypes that we might lose our identity that is secured by belonging to a 'we' group and, as a result, this fear leads to an attitude against others and strangers"” (Bańczerowski 2007: 77).

Evaluation and emotional effect can be made through realia and symbols typical of a given national group or its culture or religion: egyiptomi székely 'Egyptian Szekler, i.e. Jew', пискюл, фес, рязан пищов 'tassel, tarboosh, circumcised - meaning Turk'; úgy él, mint egy török basa - живея като бей 'live like a Turkish pasha' живея като иарче Симеонче 'live like a king'; meglesz a törökök húsvétján - когато влезе свинка в джамия кога си дойдат евреите от хаджильк $\sim$ у събота, кога взема от евреите на гръики календи 'when the pig enters the mosque $\sim$ when the Jews come back from pilgrimage $\sim$ on Saturday when I take from the Jews on the Greek kalends = never'; барон ефенди султан без гащи 'effendi baron sultan without pants = poor person who swells with importance'; fél, mint nagypénteken a zsidó 'feel like a Jew on Good Friday'; vár, mint a zsidók a messiást 'wait like a Jew waits for the Messiah'; бягам като протестатин от nocm 'avoid like a Protestant avoids a fast'.

Hungarians and Bulgarians sometimes view certain national groups similarly, which proves the universal nature of characteristics. In most cases, however, they use different images to describe the given nations' attributes. The following hostile idioms express the Gypsies' tendency for lying and stealing: a cigány sem mond mindenkor igazat 'Gypsies don't always say the truth'; ritka cigány hazugság nélkül 'rarely a Gypsy without a lie’; beillene vajdának a cigányoknál 'he would make a (good) voivode for the Gypsies'; hamis, mint a sátoros cigány - лъже като дърт ( брадат влашки) ииганин 'lie like an old/bearded/Vlach Gypsy'; amennyi cigány, annyi tolvaj 'as many Gypsies, as many thieves'; ahány

2 The translations from Hungarian and Bulgarian specialist literature are my own throughout the article. 
cigány, annyi lopás 'as many Gypsies, as many thefts'; nem kell a cigányt lopni tanítani 'you don't need to teach the Gypsy how to steal'; lop, mint a cigány крадлив като ииганин 'steal like a Gypsy'.

There are historical reasons for both languages identifying the Turkish (among others) with cruelty and aggression: úgy bánik vele, mint török a rabjával 'treat him like a Turkish treats their captive'; búsul, mint aki török rabságba esett 'he bewails as if he fell into Turkish captivity'; jaj, kinek török a szomszédja 'woe to those whose neighbours are Turkish'; rossz szomszédság török átok 'bad neighbours - a Turkish curse'; турчин и куче все едно е 'the Turkish and the dog are the same'; на турчина достлука е на коляното му 'the friendship of the Turkish is on their knees'; като в турско робство 'like under Ottoman yoke'; по-зле от турско робство 'worse than under the Ottoman yoke'.

There is, however, an insignificant number of idioms within the analysed material that show semantic or morphologic similarities or sameness: fekete, mint a szerecsen ( a cigány) - черен като чиганин ( арапин) 'black like a Gypsy ( a black man)'; minden cigány a maga lovát dicséri - всеки циганин своя кон хвали 'every Gypsy praises their own horse'; ravasz, mint a görög - лъжлив като грък 'lying/cunning like a Greek'; fél, mint zsidó a kereszttól - бягам като евреин от $\kappa р ъ c m$ 'be afraid of something/avoid something like a Jew of a cross'; sötét balkáni alak - тъмен балкански субект 'dark Balkan person'.

The most common participants in idioms and proverbs are Gypsies, Slovaks, Jews, Germans, and Vlachs. In Bulgarian phraseology, it is mainly the Turks, the Greeks, the Gypsies, the Vlachs, the Albanians, and the Jews that are the targets of prejudicial thinking, innocent mockery, and degrading or derisive humour. Some other ethnicities living in neighbouring countries are excluded from this circle. Neither Ede Margalits nor (fifty years later) Gábor O. Nagy list in their comprehensive collections of Hungarian sayings and proverbs any expressions about Croatians or Ukrainians (Rusyns). Similarly, in the Bulgarian phraseological collections (such as Najden Gerov's), only the southern neighbours of Bulgaria are mentioned, and there are no examples of Serbs.

It is to be noted that a certain portion of the phrasemes containing national denotations have faded historically and become obsolete. This process is determined by objective, historical reality as well as by a nation's subjective interpretation of the familiar and known as opposed to the foreign and unknown. The ethnonymic expressions registered in lexicons reflect interethnic relations and approaches dating from one or more hundred years ago and "depend on the spirit of that time, the ideological and religious beliefs and the conditions and tendencies dominating the country" (Bańczerowski 2007: 84). For this reason, beliefs and judgments regarding certain nations and ethnic groups cannot be absolutized for today. Qualifications preserve a given cultural community's collective memory and reflect their traditional beliefs. Since they are solidified in 
the social and national consciousness and have been passed on from generation to generation, they have become an organic part of the linguistic and cultural images of national communities and ethnic groups.

In both Hungarian and Bulgarian languages, one will find sayings and proverbs that contain opposites consisting of auto- and heterostereotypes regarding outsiders, strangers, and "us": az oláhnak tenni, a magyarnak ígérni 'what doing is for Vlahs is promising for Hungarians'; franciának hajpor, magyarnak jó bor 'hair powder for the French, good wine for Hungarians'; magyarnak kalács, németnek korbács 'cake for the Hungarians, whip for the Germans'; българин като забогатее, къща прави, а турчинът-жена зема 'when the Bulgarian becomes rich, they build a house, the Turkish gets a woman'; да те пази господ от българин погърчен и от чифутин потурчен 'God keep you from a Bulgarian who pretends to be Greek and Jew who converted to Mohammedanism'; гъриите ги съсипва салтанатът, а българите инатът 'the Greeks are spoilt by the splendour and the Bulgarians by the stubbornness'.

When contrasted with characteristics of the strangers, "our" positive or negative characteristics can be better demonstrated.

The Hungarian national self-image is very diverse and sometimes even contradictory. We can find examples of glorifying the Hungarians and the Hungarian nation as well as of criticizing them: Félni, rettegni nem tud a nagyar. 'Hungarian cannot be afraid'; A magyar, ha szépen kérik, az ingét is odaadja. 'If asked politely, Hungarians give away even their shirt'; Ha két magyar együtt van, háromfelé húz. 'If there are two Hungarians together, they pull three different ways'; Átok fogta meg a magyart, mert az soha együtt nem tart. 'Hungarians are cursed because they never stick together'; Csata után okos a magyar. 'The Hungarian is smart after a battle.'

Bulgarians often express their self-criticism in the form of derisive selfjudgment: $Y$ българин инат, у грък салтанат, у френк мурафет. 'Bulgarians have stubbornness, Greeks splendour, French skilfulness'; На българина умът иде я кога бяга, я кога ляга. 'Bulgarians become smarter when they run or when they lie down'; Хубава работа, ама българска. 'nice work (job) but Bulgarian'; Хубаво ли е или българско 'is it nice or Bulgarian'; типично българско типично по български 'typically Bulgarian - said with irony if something was not successful'.

This kind of self-criticism can partly be explained by the Bulgarians' inferiority complex: they tend to underestimate and look down upon what is their own, what is related to their country and regard highly what is different, Western or European, even if it does not fit their own life style or way of thinking.

Defining what is our own and what is foreign is based on mutual evaluation our disadvantages and deficiencies become the advantages and merits of the other (като швейцарски часовник 'like a Swiss watch' means a very precise person). 
The foreign appears as the desired place or promise of belonging somewhere else: чувствам се като европееи 'I feel European'. However, getting under the influence of what is foreign and mimicking strangers evoke negative connotations: törököt játszik 'pretends to be Turkish'; magyar az ízre, német a színre 'Hungarian to taste, German to colour' (in an abstract sense: Hungarian inside, German outside); fele magyar, fele tót 'half Hungarian, half Slovak'; egy csepp magyar vér nem folyik erében 'not a drop of Hungarian blood is in his veins'; да те пази господ от влах погърчен и от шоп потурчен 'God keep you from a Vlach who pretends to be Greek and a shop (Bulgarian from Sofia area) who converted to Mohammedanism'; ни турчин, ни българин 'neither Turkish, nor Bulgarian'; гърчея се, турчея се, македонея се, американча се, европейча се 'pretend to be Greek, Turkish, Macedonian, American, European'.

Relations with other nations, ethnic groups, and communities are limited to outside and appearance-related differences and characteristics, and the languages of "strangers" are parodied as exotic languages to express aversion. In both Hungarian and Bulgarian phrasemes, kínai (китайски), meaning 'Chinese', symbolizes inconcievable, unexplainable information and incomprehensible speech: valakinek valami kínai 'it is Chinese to somebody' като китайско писмо 'like Chinese writing'.

Besides Chinese, Hungarians use Arabic, whereas Bulgarians use Indian or Patagonian to express incomprehensibility - that is, languages of geographically faraway countries: Aki nem tud arabusul, ne beszéljen arabusul 'if you don't know Arabic, don't speak Arabic'; тъмна Индия 'it is dark India for me'.

This approach is completely different from that of other nations. In German, for example, incomprehensible or nonsensical is embodied by names of the closest neighbours of the speakers (das sind mir böhmische Dörfer; das sind mir spanische Dörfer; das kommt mir böhmisch vor 'these are Bohemian/Spanish villages; this is Bohemian to me').

Idioms that have the speakers' native language in them are the opposites of phrasemes expressing the incomprehensiveness of foreign speech. Naturally, a native language is identified with what is known and understandable: magyarul/ magyarán szólva/megmondva 'speaking in Hungarian', i.e. understandable; $н а$ чист български 'in pure Bulgarian language'. Both the Hungarians and Bulgarians consider and call their language "sweet" since it is the bearer of their culture and the most important determinant and conveyor of their identity: édes anyanyelvünk, родна реч омайна, сладка 'sweet, enchanting mother tongue'.

Phrases like Български разбираш ли? Не разбираш ли от български? 'don’t you understand Bulgarian?', Аз на български ли ти говоря? 'am I speaking Bulgarian to you?' express the speaker's dissatisfaction with their partner in communication, who does not seem to understand what they are trying to say. 
Comparing the phrasemes of two structurally very diverse languages made it possible to demonstrate certain universal semantic characteristics of the foreign and the difference in their linguistic manifestations. Besides its practical functions, foreign language learning also provides a linguistic prerequisite for broadening our knowledge: it modifies the primary model of the world created by our native tongue and provides new perspectives for us by showing different ways to learn about people and the world in general. The attitude towards the foreign coded in Hungarian and Bulgarian phraseological units is of an emotional and judging nature. It expresses distrust for the unknown and also a subjective conviction that when compared to others, the own is superior. Our observation and reasoning support the statement that dividing the world into "I and the other" and "we and the others" "reflect a certain self-defensive mental process" (Bańczerowski 2007: 77). In the linguistic image of the world, the division between the own and foreign is meant to emphasize a given linguistic and ethnocultural community's identity and strengthen its cohesion.

Today, when unified Europe is like an organization consisting of many nations, encountering otherness (other people, objects, flavours, and so on) is an everyday occurrence. Throughout history - and especially in recent years, due to the refugee crisis - we, Europeans (having complex and rich identities), have gained a significant amount of experience about how harmful and destructive the growth of intolerance, the policy of not accepting otherness, extreme national pride and aggressive patriotism can be; of how much damage can be caused by artificially induced debates about the foreign and by the hidden, smouldering tension. Attempts to violate ethnic or religious identity or to promote covert or aggressive ethnic cleansing will lead nowhere. They are destructive, shortsighted, and irrational political acts that not only prevent every chance of integration but also turn loyal citizens into terrorists, secular personalities into religious fanatics, and humane people into barbarians. They make enemies out of people who have been living together in peace for centuries, lessening the efficiency of social cooperation and condemning certain states and nations to dependency, stagnation, and poverty. It is obvious that the principles of equality, partnership, and mutual respect have to be followed for the sake of the common good, and otherness has to be accepted without judgment and prejudice. The more we know about other cultures and people representing them, the less conflict we will have to be confronted with. For this reason, in today's globalized world, multicultural and multinational communities realize more and more how important it is to have dialogues between different cultures, to protect our identity and to understand and respect others, or, in other words, to have ethnic tolerance and the equality of national cultures. 


\section{References}

Balázsi, József Attila. 2001. A cigány szó és származékai pejoratív kifejezésekben. [The Gypsy Word and Its Derivatives in Pejorative Expressions]. Magyar Nyelv 97(3): 313-324.

— 2002. "Virágnak mondod, pedig nem az...” Hasonlatok és szóláshasonlatok. ["You Call It a Flower, but It Is Not..." Similes and Fixed Similes.] Budapest: Tinta Könyvkiadó.

Bańczerowski, Janusz. 2007. Nemzeti sztereotípiák a magyar és a lengyel közmondásokban és frazeológiai kapcsolatokban. [National Stereotypes in Hungarian and Polish Proverbs and Phraseologisms]. Magyar Nyelvór 131(1): 74-87.

Bárdosi, Vilmos, ed. 2003. Magyar Szólástár [Dictionary of Hungarian Idioms and Proverbs]. Budapest: Tinta Kiadó.

Kövecses, Zoltán. 1998. Magyar szlengszótár [Dictionary of Hungarian Slang]. Budapest: Akadémiai Kiadó.

Margalits, Ede. 1897. Magyar közmondások és közmondásszerú szólások [Hungarian Proverbs and Proverbial Phrases]. Budapest: Kiadja Kókai Lajos a Millenium Évében.

Pusztai, Ferenc, ed. 2003. Magyar Értelmezô Kéziszótár, 2. átdolgozott kiadás. [Hungarian Explanatory Dictionary, $2^{\text {nd }}$ revised edition]. Budapest: Akadémiai Kiadó.

O. Nagy, Gábor. 1976. Magyar szólások és közmondások [Hungarian Sayings and Proverbs]. Budapest: Gondolat Kiadó.

Анкова-Ничева, Кети и дР. 1974-1975. Фразеологичен речник на българския език [Ankova-Nicheva, Keti. Idiom Dictionary of the Bulgarian Language]. T. I-II, София: Издателство на БАН.

Армянов, Георги. 1993. Речник на българския жаргон [Armianov, Georgi. Dictionary of Bulgarian Slang]. София: ИГ 7М+Логис.

Геров, Найден. 1895-1904. Речник на блъгарский язык, Часt I-V [Gerov, Nayden. [Dictionary of the Bulgarian Language]. Пловдив: Дружествена печатница „Сьгасие”.

Григоров, Милко-Кацаров, Костадин (съст.). 1986. Български пословици и поговорки (3. прераб. изд.) [Grigorov, Milko-Katsarov, Kostadin. Bulgarian Sayings and Proverbs]. София: Наука и изкуство.

Ничева, Мира. 2002. Фразеологичен речник на българския език [Nicheva, Mira. Idiom Dictionary of the Bulgarian Language]. ловдив: ИК Хермес.

Радева, Василка. 2004. Български тълковен речник [Radeva, Vasilka. Bulgarian Explanatory Dictionary]. ловдив: ИК Хермес. 
Славейков, Nemко Р. 1972. Български притчи или пословищи и характерни думи [Slaveykov, Petko R. Bulgarian Parables or Proverbs and Characteristic Words]. София: Издателство на БАН.

Български фрази и изрази [Bulgarian Phrases and Expressions]. URL: http:/frazite. com (last accessed on: 7 January 2017). 